Emmen, M.J., Meijer, S.A., Heideman, J.M.C., Laurant, M.G.H., Verhaak, P.F.M. Versterking van de eerstelijns GGZ: effecten op langere termijn. TSG: Tijdschrift voor Gezondheidswetenschappen: 2007, 85(3), 166

\begin{tabular}{|l|l|}
\hline $\begin{array}{l}\text { Postprint } \\
\text { Version }\end{array}$ & 1.0 \\
\hline Journal website & www.tsg.bsl.nl/ \\
\hline Pubmed link & \\
\hline DOI & \\
\hline
\end{tabular}

This is a NIVEL certified Post Print, more info at http://www.nivel.eu

\title{
Versterking van de eerstelijns GGZ: effecten op langere termijn
}

\author{
M.J. EMMEN ${ }^{1}$, S.A. MEIJER ${ }^{2}$, J.M.C. HEIDEMAN ${ }^{3}$, M.G.H. LAURANT ${ }^{3}$, P.F.M. VERHAAK ${ }^{1}$ \\ ${ }^{1}$ Nederlands instituut voor onderzoek van de gezondheidszorg (NIVEL), Utrecht \\ ${ }^{2}$ Rijksinstituut voor Volksgezondheid en Milieu (RIVM), centrum VTV, Bilthoven \\ ${ }^{3}$ Centre for Quality of Care Research (WOK), UMC St Radboud Nijmegen
}

\begin{abstract}
Improving primary mental health care: long term effects This article studies the effects of a number of measures to support general practitioners in providing primary mental health care: have these measures caused improvements and have previous effects continued? Results of a baseline questionnaire to evaluate the program in 2001 are compared with two follow-up questionnaires in 2003 and 2005. In 2001, 2003 and 2005 1336, 1359 and 729 general practitioners, respectively, filled in and returned the questionnaire. General practitioners' experience is that, from 2001 onwards, increased support by secondary mental health care, in particular support by primary health care psychiatric nurses, has lightened their workload in this field. General practitioners are more positive about collaboration with primary care psychologists and remain positive about collaboration with secondary mental health care. General practitioners attend fewer courses about mental health issues. The number of referrals within primary mental health care and to secondary mental health care remains unchanged. It seems that general practitioners prefer to invest in close collaboration with mental health workers, rather than to invest in providing mental health care themselves. Keywords: general practice, mental health care, workload, collaboration
\end{abstract}

In dit artikel wordt nagegaan of de maatregelen ter versterking van de eerstelijns Geestelijke Gezondheidszorg (GGZ) bij huisartsen tussen 2001 en 2005 tot verbeteringen geleid hebben en of eerder vastgestelde effecten van de maatregelen beklijven. Daartoe zijn de resultaten van een huisartsenque^te ter evaluatie van het GGZ beleid in 2001, 2003 en 2005 met elkaar vergeleken. De vragenlijst is in deze jaren door respectievelijk 1336, 1359 en 729 huisartsen voldoende ingevuld. Vanaf 2001 ervaren huisartsen minder werkbelasting op het gebied van de GGZ door een sterkere ondersteuning van de tweede lijn, met name door de inzet van Sociaal Psychiatrisch Verpleegkundigen. De huisarts oordeelt positiever over de samenwerking met de eerstelijnspsycholoog en blijft positief over de samenwerking met de tweedelijns GGZ. Huisartsen zijn minder scholing over GGZ onderwerpen gaan 
Emmen, M.J., Meijer, S.A., Heideman, J.M.C., Laurant, M.G.H., Verhaak, P.F.M. Versterking van de eerstelijns GGZ: effecten op langere termijn. TSG: Tijdschrift voor Gezondheidswetenschappen: 2007, 85(3), 166

volgen. Het aantal verwijzingen naar de eerste en tweedelijns GGZ is onveranderd gebleven. Over de tijd lijkt de huisarts minder te investeren in het zelf behandelen van psychische problematiek, en meer te gaan investeren in een goede samenwerking met GGZ hulpverleners.

\section{INLEIDING}

Versterking van de eerstelijns Geestelijke Gezondheidszorg (GGZ) is sinds het uitkomen van de Beleidsvisie Geestelijke Gezondheidszorg in 1998 speerpunt van het overheidsbeleid. De overheid streeft er naar dat mensen met psychische en sociale problemen zo mogelijk in de eerstelijns GGZ behandeld worden en anders gericht verwezen worden naar de specialistische tweedelijns GGZ. Hulpverleners in de eerstelijns GGZ zijn de huisarts, het algemeen maatschappelijk werk (AMW) en de eerstelijnspsycholoog (ELP). Onder de tweedelijns GGZ vallen onder andere de Regionale Instituten voor Ambulante Geestelijke Gezondheidszorg (RIAGG's), psychiatrie en psychiatrische afdelingen van een algemeen ziekenhuis (PAAZ) en zelfstandig gevestigde psychiaters, psychotherapeuten en psychologen. Om de eerstelijns GGZ te versterken is in de eerste vijf jaar van deze eeuw een groot aantal maatregelen uitgevoerd (zie box 1). Het idee achter de versterkende maatregelen was dat ze een positieve invloed zouden uitoefenen op de behandelcapaciteit van de eerstelijns GGZ, op de samenwerking tussen eerstelijns partijen en tussen eerstelijns en tweedelijns GGZ en op de deskundigheid van de verschillende soorten hulpverleners in de eerstelijn. Toegenomen capaciteit, meer samenwerking en meer deskundigheid zouden ertoe moeten leiden dat meer mensen die in de eerstelijn behandeld kunnen worden daar ook daadwerkelijk behandeld zouden worden. De effecten van deze maatregelen zijn uitvoerig bestudeerd in een landelijke evaluatiestudie die startte in 2001 en liep tot de zomer van 2004. Hiertoe werd onder andere een uitgebreide groep huisartsen (ongeveer 1350 personen) in 2001 en 2003 schriftelijk ondervraagd. Hierover is gerapporteerd. ${ }^{1-5}$ In de evaluatiestudie van Meijer et al. ${ }^{5}$ werd geconstateerd dat het pakket versterkende maatregelen conform de voornemens was uitgevoerd. Een aantal nagestreefde effecten werd ook bewerkstelligd. Er was sprake van een toegenomen capaciteit aan hulpverlening binnen de eerstelijn, de samenwerking tussen huisartsen en de ambulante GGZ was verbeterd, vooral door de inzet van Sociaal Psychiatrisch Verpleegkundigen (SPV-en) en consultatieve psychiaters binnen de eerstelijn, en er werden, mede dankzij de inzet van die SPV-en, meer patie"nten binnen een eerstelijns context behandeld. Minder verandering werd geconstateerd in de samenwerking tussen de eerstelijns partijen. Ook was er weinig verandering in de GGZ verwijsstromen in het algemeen. Landelijk bleven huisartsen evenveel binnen de eerstelijn en naar de tweedelijns GGZ verwijzen als ze voor de versterkende maatregelen deden. In een aantal opzichten konden effecten ten tijde van de tweede meting van de evaluatiestudie nog niet verwacht worden. De projecten onder huisartsen om de kwaliteit van de GGZ te bevorderen waren op dat moment nauwelijks afgerond, nog lopende en soms nog maar gedeeltelijk ingezet, hetzelfde gold voor de samenwerkingsprojecten Korte Lijnen. Van een aantal effecten die wel gevonden waren, was het de vraag of ze blijvend zouden zijn. En bij sommige effecten die (nog) niet opgetreden waren, kon de vraag gesteld worden of ze op langere termijn we'l zouden optreden. Dit alles vormde aanleiding om de genoemde enquête nog een keer af te nemen onder de huisartsen die de vragenlijst zowel in 2001 als in 2003 ingevuld hadden. De vragen die met deze derde meting behandeld worden zijn: Is het uitvoeren van GGZ-taken op lange termijn minder belastend voor de huisarts geworden? Zijn er in de samenwerking binnen de eerstelijns GGZ op langere termijn wel verbeteringen opgetreden? Heeft de verbetering in samenwerking tussen huisartsen en tweedelijns GGZ zich op langere termijn gehandhaafd? Hoe heeft de deskundigheidsbevordering van huisartsen zich na de kwaliteitsprojecten GGZ ontwikkeld? Zijn er op langere termijn wijzigingen in de verwijspatronen van huisartsen opgetreden? 
Emmen, M.J., Meijer, S.A., Heideman, J.M.C., Laurant, M.G.H., Verhaak, P.F.M. Versterking van de eerstelijns GGZ: effecten op langere termijn. TSG: Tijdschrift voor Gezondheidswetenschappen: 2007, 85(3), 166

\section{[Box 1]}

\section{METHODE}

\section{Dataverzameling en respons}

De enque^tes uit 2001 en 2003 werden gezamenlijk door het Nederlands instituut voor onderzoek van de gezondheidszorg (NIVEL) en het Centre for Quality of Care Research van het UMC St Radboud (WOK) uitgezet en geanalyseerd. In 2001 werd een steekproef, gestratificeerd naar district, praktijkvorm en urbanisatiegraad getrokken uit het Nederlandse huisartsenbestand. Er werd per huisartspraktijk slechts e'e'n huisarts aangeschreven. Het steekproefkader omvatte 2757 huisartsen. Om de response op de vragenlijsten te vergroten zijn in 2001 en 2003 drie reminders en in 2005 twee reminders verstuurd. Figuur 1. toont de response op de drie vragenlijsten. In 2001 waren de ingevulde vragenlijsten van 1336 huisartsen (49\%) geschikt voor analyse. Non-respondenten is een verkorte vragenlijst toegestuurd, met een aantal kernvragen uit de oorspronkelijke vragenlijst over de samenwerking met andere GGZ hulpverleners, die door 643 huisartsen geretourneerd is. In 2003 is het volledige steekproefkader uit 2001 weer aangeschreven. Van 1359 huisartsen was de vragenlijst bruikbaar, hetgeen, na correctie voor ten onrechte aangeschreven huisartsen (inmiddels gestopt met praktijk) en oningevulde vragenlijsten een bruikbare respons is van 52\%. Ook hier kregen non-respondenten een verkorte vragenlijst die door 485 huisartsen werd geretourneerd. Een groep van 931 huisartsen heeft zowel in 2001 als 2003 de enquête ingevuld. Dezen zijn aangeschreven voor de derde meting. Hiervan bleken 18 huisartsen niet meer praktiserend. Ee'n huisarts was langdurig ziek. De bereikte doelgroep bestond dus uit 912 huisartsen. Van 729 huisartsen waren de ingevulde vragenlijsten geschikt voor analyse. De bruikbare respons komt hiermee op 80\%.

\section{[FIGUUR 1]}

\section{Vragenlijst}

De formulering van de items in de opeenvolgende vragenlijsten bleef gelijk, maar de vragenlijst is over de tijd wel steeds korter geworden door items weg te laten waarop weinig verandering meer verwacht kon worden. Vragen met betrekking tot de tweedelijns GGZ zijn in de derde vragenlijst beperkt tot de regionale Ambulante Geestelijke Gezondheidszorg (AGGZ) respectievelijk de RIAGG. Volgens de eerste twee enque^tes waren dit de meest gebruikte tweedelijns contacten. Psychiatrie en PAAZ, vrijgevestigde psychiaters en psychotherapeuten en verslavingszorg zijn buiten beschouwing gelaten. Er zal alleen over de gezamenlijke items uit de drie vragenlijsten gerapporteerd worden. De items hebben betrekking op werkbelasting als gevolg van GGZ hulpverlening, samenwerking met eerste en tweedelijns GGZ, deskundigheidsbevordering GGZ en verwijzingen naar de eerste en tweedelijns GGZ.

\section{Variabelen}

Werkbelasting als gevolg van GGZ hulpverlening wordt uitgedrukt in de geschatte duur van een normaal consult en van een GGZ consult, het geschatte percentage GGZ consulten van alle consulten, percentage huisartsen dat meer dan e'én knelpunt in GGZ hulpverlening ervaart (maximum is vier knelpunten), percentage huisartsen dat gebruik maakt van een speciale regeling om werkbelasting te verlichten en percentage dat betrokken is bij een consultatief project. De samenwerking met het AMW, de ELP en de ambulante GGZ wordt afzonderlijk uitgevraagd. De samenwerking wordt uitgedrukt in percentage huisartsen dat kennis heeft over meer dan e'én hulpverleningsaspect zoals werkwijze of namen van hulpverleners (bij AMWen ELP: maximum van vijf aspecten; bij de ambulante GGZ: maximum van 6 aspecten), percentage huisartsen dat bijna altijd bericht krijgt over intake en/of de voortgang en/of het resultaat van de behandeling, rapportcijfers van 1 tot 10 over de 
Emmen, M.J., Meijer, S.A., Heideman, J.M.C., Laurant, M.G.H., Verhaak, P.F.M. Versterking van de eerstelijns GGZ: effecten op langere termijn. TSG: Tijdschrift voor Gezondheidswetenschappen: 2007, 85(3), 166

kwaliteit van de berichtgeving en kwaliteit van het overleg, percentage huisartsen dat geregeld overleg heeft en percentage huisartsen dat meer dan e'én knelpunt in de samenwerking ervaart (maximum van vier knelpunten). Deskundigheidsbevordering GGZ wordt gepresenteerd aan de hand van het geschatte aantal uren scholing over een GGZ onderwerp en het percentage GGZ scholing van het totale aanbod aan scholing. Verwijzingen worden apart uitgevraagd voor het AMW, de ELP en de ambulante GGZ. Huisartsen hebben het aantal patie"nten dat ze in het voorgaande jaar verwezen naar de desbetreffende instantie of hulpverlener geschat. Dit aantal is uitgedrukt in het aantal per 1000 patie"nten van een betreffende huisarts.

\section{Data-analyse}

We vergelijken in principe alle respondenten van de successievelijke metingen. Voor de jaren 2001, 2003 en 2005 worden de gegevens van respectievelijk 1336, 1359 en 729 huisartsen gebruikt. De resultaten zijn geanalyseerd met het statistiekprogramma SPSS. Er is voornamelijk beschrijvende statistiek toegepast: frequentieverdelingen, gemiddelden en percentages. Er is getoetst of er verschillen zijn tussen 2001, 2003 en 2005. Daar waar verschillen in gemiddelde scores zijn getoetst, is gebruik gemaakt van een ANOVA. Om te zien waar de verschillen zitten, zijn er post hoc tests uitgevoerd (Bonferroni). Daar waar verschillen in verdeling zijn getoetst, is gebruik gemaakt van een chikwadraat toets (bij crosstabs). Een p-waarde kleiner dan 0,01 is significant. Teneinde na te gaan of gevonden veranderingen in de tijd niet toegeschreven kunnen worden aan de veranderde samenstelling van het onderzoekscohort zijn er ook herhaalde metingen analyses verricht voor de groep respondenten die alle drie de vragenlijsten heeft ingevuld $(\mathrm{N}=729)$.

\section{RESULTATEN}

\section{Studiepopulatie}

De respondenten in 2001, 2003 en 2005 komen sterk overeen in achtergrond kenmerken. Meer dan driekwart van de respondenten is mannelijk. Iets meer dan de helft werkt in een solopraktijk, een kwart in een duopraktijk en ongeveer $14 \%$ in een groepspraktijk of gezondheidscentrum. Meer dan de helft van de huisartsen die deelnamen, valt in een leeftijdcategorie van 45 tot 55 jaar. Wanneer de gegevens van de respondenten vergeleken worden met de gegevens van de Nederlandse huisartsen bevolking zoals vastgelegd in de huisartsregistratie van het NIVEL 2001, 2003 en $2005^{6-8}$ dan blijken de respondenten in 2001 en 2003 vergelijkbaar te zijn en de respondenten in 2005 iets ouder en vaker mannelijk te zijn en vaker in een solopraktijk te werken.

\section{Werkbelasting}

Een gemiddeld consult duurt volgens de huisartsen ongeveer 10 minuten (tabel 1). Een gemiddeld consult bij patie"nten met psychische of sociale problematiek nam naar schatting van de huisarts gemiddeld 19-20 minuten in beslag. Het percentage consulten dat patie"nten met psychische of sociale problemen betreft is in 2003 en 2005 in vergelijking met 2001 afgenomen. Door de tijd genomen, blijken steeds minder huisartsen knelpunten te ervaren in de zorg aan patie"nten met psychische en sociale problemen. Met name "te weinig tijd" en “'te veel taken hebben”, worden in latere jaren door steeds minder huisartsen als knelpunten ervaren. De vraag of de huisarts speciale maatregelen heeft getroffen om de werkbelasting die de uitvoering van de GGZ hulpverlening met zich meebrengt te beperken, werd in 2001 door 19\%, in 2003 door 35\% en in 2005 door $49 \%$ van de huisartsen bevestigend beantwoord. Dergelijke maatregelen betroffen soms het zelf meer tijd inruimen voor consulten over psychische problemen, soms het aantrekken van praktijkondersteuning, het inhuren van een psycholoog of AMW-er, maar meestal werd een SPV in de praktijk ingezet. Ook het percentage huisartsen dat betrokken is bij een consultatief project, waarbij consultatie vanuit de gespecialiseerde GGZ aan de eerstelijn wordt gegeven, is in 2005 in vergelijking met 2001 en 2003 sterk toegenomen. In 2005 was de helft van de huisartsen bij 
Emmen, M.J., Meijer, S.A., Heideman, J.M.C., Laurant, M.G.H., Verhaak, P.F.M. Versterking van de eerstelijns GGZ: effecten op langere termijn. TSG: Tijdschrift voor Gezondheidswetenschappen: 2007, 85(3), 166

een consultatief project betrokken. Ook hieronder wordt in negen van de tien gevallen de inzet van een SPV verstaan.

\section{[TABEL 1]}

\section{Samenwerking binnen de eerstelijns GGZ}

In tabel 2 is terug te vinden wat huisartsen in 2001, 2003 en 2005 meldden over de samenwerking met de eerstelijns GGZ.

\section{[TABEL 2]}

\section{Samenwerking met het AMW}

De enque^te laat geen grote veranderingen over de tijd zien op het gebied van samenwerking met het AMW. Het merendeel van de huisartsen is op de hoogte van e'én of meer hulpverleningsaspecten zoals de namen van hulpverleners en werkwijze. Slechts een kwart van de huisartsen ontvangt regelmatig bericht van het AMWen heeft geregeld overleg over individuele patie"nten. In 2003 beoordelen de huisartsen de kwaliteit van de berichtgeving minder goed dan in 2001 maar in 2005 wordt de kwaliteit weer wat beter beoordeeld. Niettemin blijt de gemiddelde beoordeling van de kwaliteit ( 5 op een schaal van 10) laag. Meer dan de helft van de huisartsen ervaart wel e'é $n$ of meer knelpunten in de samenwerking met het AMW. Van een maximum van vier knelpunten in de samenwerking met het AMW, ervaren huisartsen er gemiddeld e'én. De belangrijkste knelpunten worden gevormd door wachttijden, gebrek aan inzicht in de organisatiestructuur van de AMW instelling en te weinig mogelijkheden om gezamenlijk te behandelen. Het aantal huisartsen dat knelpunten ervaart neemt wel af over de tijd. Dit komt vooral doordat tussen 2001 en 2003 minder huisartsen de wachttijden bij het AMW als een knelpunt zijn gaan opvatten. Indien er een ad hoc analyse wordt verricht waarbij onderscheid gemaakt wordt naar de diverse praktijkvormen, dan is de samenwerking met het AMW van huisartsen in een gezondheidscentrum aanzienlijk beter dan van huisartsen in een solo, duo of groepspraktijk. Echter, slechts 15\% van de huisartsen werkt in een gezondheidscentrum.

\section{Samenwerking met de eerstelijnspsycholoog}

De samenwerking met de eerstelijnspsycholoog is in een aantal opzichten in de loop van de tijd beter geworden. Steeds meer huisartsen geven aan op de hoogte te zijn van de hulpverlening door de eerstelijnspsycholoog. In vergelijking met 2001 en 2003 geven meer huisartsen aan geregeld overleg te hebben met de eerstelijnspsycholoog over individuele patie"nten. Ook het aantal huisartsen dat knelpunten ervaart in de samenwerking met de eerstelijnspsycholoog is over de tijd afgenomen. De meeste “winst”' is tussen 2003 en 2005 geboekt. Ook hier zijn het met name de wachttijden die minder als knelpunt worden genoemd. Huisartsen geven van een maximum van vier knelpunten in de samenwerking met de eerstelijnspsycholoog gemiddeld minder dan één knelpunt aan.

\section{Samenwerking met de tweedelijns GGZ}

De samenwerking tussen de huisarts en de tweedelijns GGZ is in de periode van 2001 tot 2005 verbeterd (tabel 3). In de loop van de tijd raken meer huisartsen op de hoogte van de hulpverlening door de ambulante GGZ. De toename in het percentage huisartsen dat geregeld overleg heeft met de ambulante GGZ over individuele patie"nten heeft zich na 2003 voortgezet. In vergelijking met 2001 beoordelen de huisartsen in 2005 zowel de kwaliteit van berichtgeving als de kwaliteit van overleg met individuele patie"nten beter. Het percentage huisartsen dat knelpunten ervaart in de samenwerking met de ambulante GGZ is in 2005 in vergelijking met 2001 verder afgenomen. Minder huisartsen zien wachttijden als knelpunt, minder huisartsen vinden het moeilijk om patie"nten te motiveren om naar de tweedelijn te gaan en vaker zien huisartsen gezamenlijke behandeling als mogelijkheid bij een tweedelijns verwijzing. Van een maximum van vier knelpunten ervaren huisartsen er gemiddeld meer dan 1 in de samenwerking met de ambulante GGZ. Over alle jaren geldt dat 
Emmen, M.J., Meijer, S.A., Heideman, J.M.C., Laurant, M.G.H., Verhaak, P.F.M. Versterking van de eerstelijns GGZ: effecten op langere termijn. TSG: Tijdschrift voor Gezondheidswetenschappen: 2007, 85(3), 166

het percentage huisartsen dat knelpunten ervaart in de samenwerking met de ambulante GGZ groter blijft dan het percentage huisartsen met knelpunten in de samenwerking met het AMWof de eerstelijnspsycholoog: de gepercipieerde wachttijden blijven langer en het blijft lastiger om een patie"nt voor een verwijzing te motiveren dan bij de eerstelijnspartijen. Echter, de ondoorzichtige organisatie structuur en beperkte mogelijkheid om gezamenlijk een patie"nt in behandeling te nemen worden in 2005 bij het AMWals even grote knelpunten gezien als bij de ambulante GGZ. In deze opzichten scoort de eerstelijnspsycholoog duidelijk beter.

\section{[TABEL 3]}

\section{Deskundigheidsbevordering}

Tabel 4 laat zien hoeveel uren bij- of nascholing in de GGZ huisartsen in de afgelopen twee jaar hebben gevolgd. Eveneens wordt het percentage GGZ bij- of nascholing ten opzichte van het totale scholingsaanbod gepresenteerd. Er is in 2003 en 2005 in vergelijking met 2001 een afname van het aantal uren scholing in de GGZ. Er is over de tijd geen grote verschuiving te zien in de GGZ onderwerpen waarvoor huisartsen scholing gevolgd hebben. Huisartsen hebben in de periode van 1999 tot 2005 verreweg de meeste scholing gevolgd over depressie. Andere onderwerpen waarover veel scholing gevolgd is, zijn persoonlijkheidsstoornissen, dementie, delier en fobie/ paniekstoornis.

\section{[TABEL 4]}

\section{Verwijsstromen}

Het aantal verwijzingen van de huisarts naar eerstelijns GGZ hulpverleners wordt getoond in tabel 5. Het aantal verwijzingen van de huisarts naar het AMW, de eerstelijnspsycholoog en de ambulante GGZ is over de periode van 2001 tot 2005 niet veranderd.

\section{DISCUSSIE EN CONCLUSIE}

In dit artikel is nagegaan of de maatregelen ter versterking van de eerstelijns GGZ bij huisartsen tussen 2001 en 2005 tot verbeteringen geleid hebben en of eerder vastgestelde effecten van de maatregelen over de tijd beklijven. Daartoe zijn de resultaten van een huisartsenque`te ter evaluatie van het GGZ beleid in 2001, 2003 en 2005 met elkaar vergeleken. Aan de hand van de eerder geformuleerde onderzoeksvragen zullen de meest relevante bevindingen besproken worden. De eerste vraag betrof de werkbelasting van het uitvoeren van GGZ taken voor de huisarts. Is deze werkbelasting op langere termijn verminderd? Over de tijd lijkt de werkbelasting inderdaad afgenomen te zijn. Huisartsen zijn in de afgelopen vijf jaren minder knelpunten gaan ervaren in het verlenen van zorg aan patie"nten met psychische of sociale problematiek. Deze afname heeft zich na 2003 ook verder doorgezet. De toenemende ontlasting van de huisarts ten aanzien van GGZ taken lijkt vooral te verklaren te zijn door een sterkere ondersteuning van de tweede lijn, met name door de inzet van SPV-en in de huisartspraktijk. De huisarts lijkt minder prioriteit bij het zelf behandelen van psychische problematiek te leggen wat onder andere af te lezen is aan de afname van het geschatte aantal GGZconsulten. De tweede en derde vraag richtten zich op het optreden van verbeteringen in de samenwerking met de eerstelijns GGZ en het handhaven van de verbeterde samenwerking met de tweedelijns GGZ op langere termijn. In 2001 was de samenwerking tussen huisartsen en de eerste en tweedelijns GGZ voor verbetering vatbaar. ${ }^{1}$ Er zou door de verschillende GGZ hulpverleners aan de huisarts meer informatie gegeven moeten worden over het proces van hulpverlening en er zou meer structureel overleg plaats moeten vinden over patie"nten. De samenwerking met het AMW is ook op langere termijn niet verbeterd. De samenwerking met de eerstelijnspsycholoog en de ambulante GGZ is wel verbeterd in de periode van 2001 tot 2005. De positieve effecten die 
Emmen, M.J., Meijer, S.A., Heideman, J.M.C., Laurant, M.G.H., Verhaak, P.F.M. Versterking van de eerstelijns GGZ: effecten op langere termijn. TSG: Tijdschrift voor Gezondheidswetenschappen: 2007, 85(3), 166

in dit laatste opzicht al geconstateerd werden aan het eind van de landelijke evaluatiestudie zijn bestendigd en zelfs nog iets sterker geworden. De verbetering in samenwerking met de eerstelijnspsycholoog kan het gevolg zijn van het Diaboloproject en het Project "Korte Lijnen”. Deze projecten werden immers ingezet om de samenwerking tussen de eerstelijns partners te verbeteren en waren ten tijde van de evaluatie in 2003 nog niet volledig gei"mplementeerd. Daarnaast kan de inzet van meer specialistische expertise met behulp van de zogenaamde consultatieregeling een verbeterde samenwerking met de ambulante GGZ tot gevolg gehad hebben. Dat de samenwerking met het AMWondanks verschillende initiatieven om deze te verbeteren gelijk is gebleven over de tijd, kan veroorzaakt zijn door bezuinigingen en taakverschuivingen binnen het AMW. In 2005 vonden er bezuinigingen bij de gemeenten plaats die doorgerekend werden naar het AMW. Bovendien zijn gemeenten hun prioriteit gaan leggen bij terreinen als overlast, huiselijk geweld en de uitvoering van de Wet Maatschappelijke Ondersteuning (WMO) en niet zozeer meer bij het thema eerstelijns GGZ. ${ }^{9}$ De ontwikkeling van de deskundigheidsbevordering van huisartsen na de kwaliteitsprojecten GGZ was het onderwerp van de vierde onderzoeksvraag. Hoewel er door middel van de kwaliteitsprojecten van de Landelijke Huisarts Vereniging (LHV) en het Nederlands Huisartsen Genootschap (NHG) getracht is een nascholingsaanbod op maat te cree"ren, is de nascholingstijd, gewijd aan GGZ, afgenomen sinds die tijd. Was het meetmoment 2003 wellicht nog te vroeg om het gebruik van het nieuwe aanbod te meten, ook op langere termijn blijkt dit geen effect gesorteerd te hebben. Huisartsen zijn niet meer prioriteit gaan geven aan nascholing op dit terrein. Mogelijkerwijs zijn huisartsen hun energie meer gaan steken in de samenwerking met andere GGZ hulpverleners zoals de eerstelijnspsycholoog en de tweedelijns ambulante GGZ en in het doorschuiven van de psychische problematiek naar met name de SPV dan in de deskundigheidsbevordering om zelf de GGZ-problematiek aan te pakken. Bovendien kan de vraag gesteld worden of de implementatie van de kwaliteitsprojecten optimaal verlopen is. ${ }^{2}$ Heideman et al. ${ }^{2}$ constateerden dat de interventies die in het kader van de kwaliteitsprojecten GGZ aangeboden werden aan de huisartsen vaak niet voldeden aan hun behoefte en dat huisartsen niet altijd meededen aan interventies indien deze aangeboden werden. Ten slotte ging de vijfde onderzoeksvraag over wijzigingen in de verwijspatronen van huisartsen op langere termijn. Het aantal verwijzingen naar het AMW, de eerstelijnspsycholoog en de ambulante GGZ is ook op langere termijn gelijk gebleven. Hoewel de maatregelen ter versterking van de eerstelijns GGZ er op gericht waren om de tweede lijn te ontlasten, is het aantal verwijzingen naar de ambulante GGZ over de tijd niet verminderd. Een mogelijke verklaring hiervoor werd al beschreven in het rapport ter evaluatie van de versterkende maatregelen van 2004. ${ }^{5}$ De consultatieregeling die oorspronkelijk bedoeld was om expertise rondom psychische problematiek uit de tweedelijn over te dragen op de eerstelijn, heeft er met name toe geleid dat SPV-en een deel van de taken van de huisarts overgenomen hebben. Hierdoor is het GGZ aanbod in de eerstelijn groter geworden. De inzet van de SPV kon er echter ook toe leiden dat clie"nten die net zo goed in de eerstelijn behandeld hadden kunnen worden, doorverwezen werden naar de tweedelijns GGZ. Er dienen enkele methodologische opmerkingen over de studie gemaakt te worden. Bij het invullen van de drie enque^tes zou selectiebias een rol gespeeld kunnen hebben. Mogelijkerwijs heeft een selecte groep van huisartsen de enque tes ingevuld. Om dit na te gaan is er in 2001 en in 2003 een korte vragenlijst over samenwerking met andere GGZ hulpverleners bij de non-respondenten afgenomen. In 2001 worden er tussen de respondenten en non-respondenten geen relevante verschillen gevonden. In 2003 wordt gevonden dat respondenten minder vaak overleggen met GGZ partners dan non-respondenten. Het gegeven dat juist onder deze huisartsen verbetering in samenwerking heeft plaatsgevonden, zou het positieve effect van de versterkingsmaatregelen kunnen benadrukken. Het zouden echter, in vergelijking met de non-respondenten die mogelijk niet meedoen omdat ze al samenwerken, ook de huisartsen met de grootste marge om te verbeteren, kunnen zijn. ${ }^{3}$ De respondenten van de enquêtes uit 2001 en 2003 zijn niet voor honderd procent dezelfde personen. (De respondenten uit 2005 
Emmen, M.J., Meijer, S.A., Heideman, J.M.C., Laurant, M.G.H., Verhaak, P.F.M. Versterking van de eerstelijns GGZ: effecten op langere termijn. TSG: Tijdschrift voor Gezondheidswetenschappen: 2007, 85(3), 166

wel, die hebben zowel op de enque te uit 2001 als op die van 2003 gereageerd). Om het mogelijke effect van deze verschillende respondenten uit te schakelen, zijn er ook analyses over de tijd uitgevoerd voor uitsluitend die huisartsen die alle enquêtes ingevuld hebben. Dit is gedaan met de analyse voor herhaalde metingen. Hierbij werden dezelfde resultaten gevonden als gepresenteerd in dit artikel. Een laatste opmerking van methodologische aard betreft de validiteit van de gegevens. De resultaten zijn gebaseerd op datgene wat de responderende huisartsen zeggen. Waar het beoordelingen en waarderingen betreft, levert dit de juiste gegevens op. Waar het gerapporteerde ervaringen betreft ("hoe vaak hebt u bericht gekregen”, “'hoeveel uur GGZ-nascholing hebt u gevolgd') speelt de herinnering een rol. Dit geldt nog sterker voor schattingen met betrekking tot het aantal verwijzingen of de duur van een consult over psychische klachten. Aangenomen wordt dat de schattingsfouten op ieder tijdstip van dezelfde orde zijn, en dat er daarom, gezien de gelijke samenstelling van de respondentgroepen op drie momenten, toch op een valide wijze van een trend in de tijd gesproken kan worden. De trend die vanaf 2001 geconstateerd wordt, is een toenemende ontlasting van de huisarts, waar het behandeling van psychische stoornissen betreft door een sterkere ondersteuning van de tweede lijn, met name door de inzet van SPV-en in de huisartspraktijk. De huisarts lijkt minder prioriteit bij het zelf behandelen van psychische problematiek te leggen, gezien het door hem geschatte aantal GGZ-consulten en de geringere deelname aan GGZ-nascholing die men rapporteert. De huisarts wordt positiever over de samenwerking met de eerstelijnspsycholoog en blijft positief over de samenwerking met de tweedelijns GGZ. Het AMW moet haar positie als belangrijke overlegpartner (van oudsher gerealiseerd binnen gezondheidscentra) naast de eerstelijnspsycholoog en de ambulante GGZ zien te behouden en met name aandacht schenken aan de berichtgeving en de ondoorzichtige organisatiestructuur van de instellingen voor de huisarts. Hoe zullen de bovengenoemde ontwikkelingen zich in de toekomst voortzetten? De toekomstige veranderingen in de financiering van de geestelijke gezondheidszorg stimuleren het marktdenken van de aanbieders en zullen de concurrentie tussen hulpverleners doen vergroten. Zal de geleidelijk toenemende samenwerking tussen de huisartsen en GGZ hulpverleners deze opkomende marktwerking en concurrentie weerstaan?

\section{LITERATUUR}

1. Heideman J, Laurant M, Lin N van, Verhaak P, Wensing M, Grol R. De samenwerking tussen huisartsen en de GGZ is voor verbetering vatbaar. Tijdschr Gezondheidswet 2006;84:22-8.

2. Heideman JM, Laurant MG, Wensing M, Grol RP. Improving primary mental health care: Impact of a nationwide programme. Health Policy 2006 Jul 15 (Epub ahead of print) 3. Heideman JM, Laurant MG, Verhaak PFM, Wensing M, Grol RP. Effects of a nationwide programme: interventions to reduce perceived barriers to collaboration and to increase structural one-on-one contact. J Eval Clin Pract. (in druk)

4. Laurant MGH. Geestelijke gezondheidszorg bij de huisarts: onderzoek van Nivel en WOK wijst op problemen. Med Contact 2001;56:1780-3.

5. Meijer SA, Zantinge EM, Verhaak PFM. Evaluatie versterking eerstelijns GGZ:

Eindrapportage landelijk onderzoek. Utrecht: NIVEL, 2004.

6. Hingstman L, Kenens R. Cijfers uit de registratie van huisartsen: peiling 2001. Utrecht: NIVEL, 2001.

7. Kenens R, Hingstman L. Cijfers uit de registratie van huisartsen: peiling 2003. Utrecht: NIVEL, 2003.

8. Kenens R, Hingstman L. Cijfers uit de registratie van huisartsen: peiling 2005. Utrecht: NIVEL, 2005.

9. Sok K, Scholte M, Veen C van der, Voordouw I. Vijf jaar korte lijnen versterking eerstelijns GGZ. Evaluatierapport. Utrecht: NIZW / Trimbos-instituut, 2005. 
Emmen, M.J., Meijer, S.A., Heideman, J.M.C., Laurant, M.G.H., Verhaak, P.F.M. Versterking van de eerstelijns GGZ: effecten op langere termijn. TSG: Tijdschrift voor Gezondheidswetenschappen: 2007, 85(3), 166

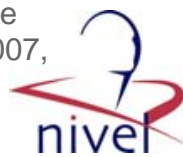

BOXEN, FIGUREN EN TABELLEN

\section{Box 1 Versterkende Maatregelen eerstelijns GGZ}

- Tijdelijke Stimuleringsmaatregel Algemeen Maatschappelijk Werk (AMW): voor iedere extra aangestelde fte uitvoerend AMW subsidieert VWS ook één fte.

- Consultatieregeling: subsidie via zorgkantoren aan GGZ instellingen om consultatieve ondersteuning aan de eerstelijn te bieden.

- Kwaliteitsprojecten in de eerstelijn. Subsidie van VWS aan de beroepsverenigingen van huisartsen, AMW en eerstelijnspsychologen om te besteden aan kwaliteitsverbetering op het gebied van de GGZ. De beroepsverenigingen van huisartsen trachtten met deze projecten o.a. nascholing te creëren die regionaal op maat van de behoefte gesneden was.

- Projecten Korte Lijnen: plaatselijke projecten om de samenwerking binnen de eerstelijns GGZ te bevorderen.

- Diaboloprojecten: Extra middelen om op lokaal niveau samenwerkingsinitiatieven te ondersteunen en best practices te stimuleren.

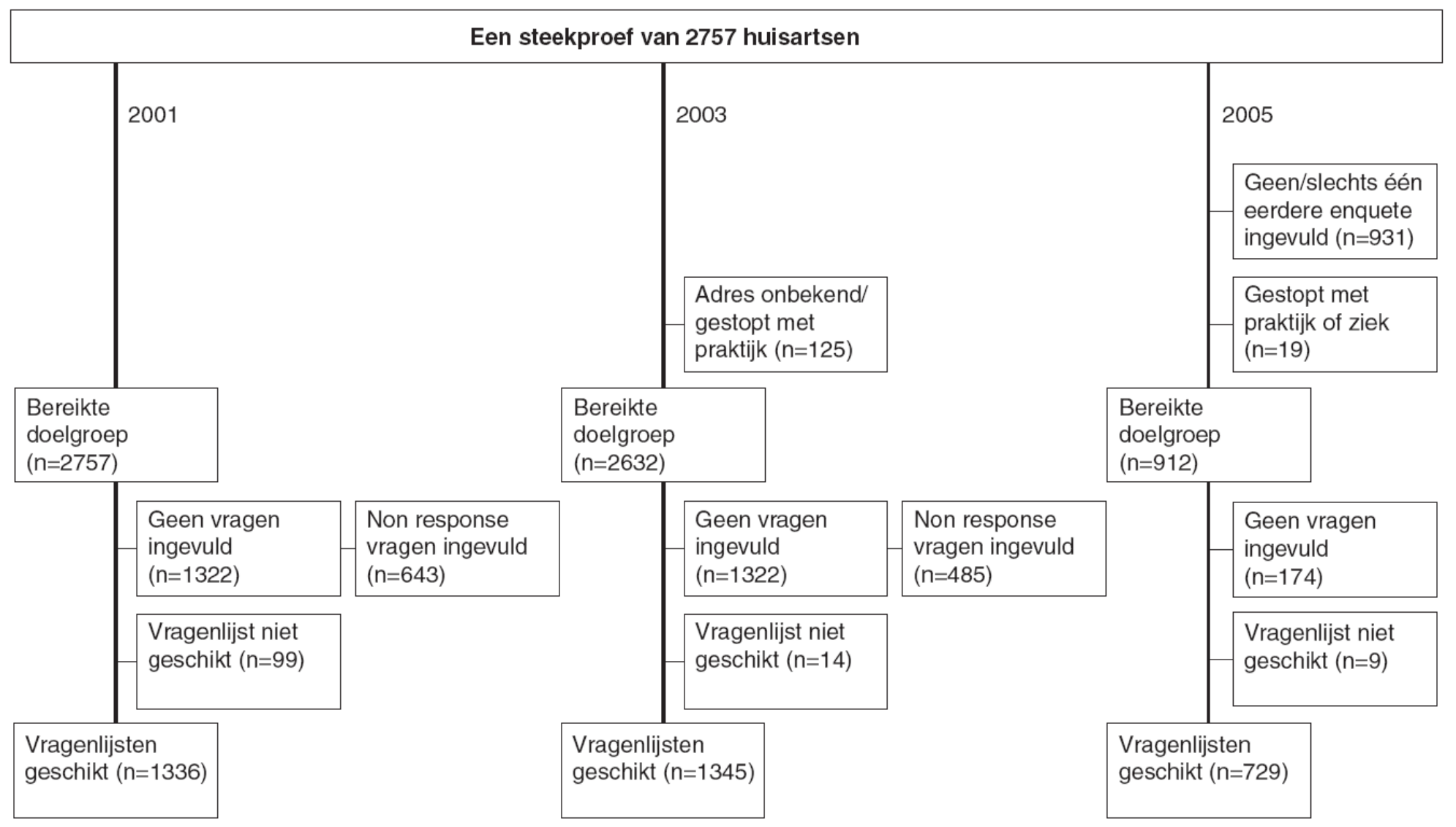

Figuur 1 De response op de huisartsenquête in 2001, 2003 en 2005. 
Emmen, M.J., Meijer, S.A., Heideman, J.M.C., Laurant, M.G.H., Verhaak, P.F.M. Versterking van de eerstelijns GGZ: effecten op langere termijn. TSG: Tijdschrift voor Gezondheidswetenschappen: 2007, 85(3), 166

Tabel 1 Werkbelasting als gevolg van GGZ en verlichtende maatregelen

\begin{tabular}{|c|c|c|c|c|}
\hline & $\begin{array}{l}2001 \\
(n=916-1323)\end{array}$ & $\begin{array}{l}2003 \\
(n=1331-1336)\end{array}$ & $\begin{array}{l}2005 \\
(n=709-726)\end{array}$ & \\
\hline Duur consult in minuten (gemiddelde, (SD)) & $10,3(3,9)$ & $10,2(1,7)$ & $10,3(1,6)$ & n.s. \\
\hline Duur consult GGZ in minuten (gemiddelde,(SD)) & $19,1(5,8)^{5}$ & $19,5(5,6)$ & $19,9(5,8)^{1}$ & $\mathrm{p}<0,01$ \\
\hline $\begin{array}{l}\text { Geschatte percentage consulten GGZ (gemid- } \\
\text { delde (SD)) }\end{array}$ & $20,7(14,3)^{3,5}$ & $19,1(13,0)^{1}$ & $17,7(13,5)^{1}$ & $\mathrm{p}<0,01$ \\
\hline Huisartsen ervaren knelpunten in GGZ zorg (\%) & 89 & 72 & 65 & $\mathrm{p}<0,01$ \\
\hline $\begin{array}{l}\text { Huisartsen met speciale regeling om werkbe- } \\
\text { lasting GGZ te verlichten (\%) }\end{array}$ & 19 & 35 & 49 & $\mathrm{p}<0,01$ \\
\hline Huisartsen betrokken in consultatief project (\%) & 39 & 39 & 51 & $\mathrm{p}<0,01$ \\
\hline
\end{tabular}

Noot: ${ }^{1,3,5}$ staan respectievelijk voor de jaren 2001, 2003 en 2005 en geven aan dat de bijbehorende waarde significant verschilt van de aangegeven jaren,

Tabel 2 Indicatoren voor samenwerking met AMW en ELP

\begin{tabular}{|c|c|c|c|c|}
\hline & $\begin{array}{c}2001 \\
(n=793-1336)\end{array}$ & $\begin{array}{c}2003 \\
(\mathrm{~N}=836-1340)\end{array}$ & $\begin{aligned} & 2005 \\
(n= & 480-728)\end{aligned}$ & \\
\hline \multicolumn{5}{|l|}{$\begin{array}{l}\text { Ervaringen van huisartsen ten aanzien van samen- } \\
\text { werking met het AMW }\end{array}$} \\
\hline $\begin{array}{l}\text { Kennis van hulpverleningsaspecten: namen en } \\
\text { werkwijze (\%) }\end{array}$ & 85 & 86 & 86 & n.s. \\
\hline Bericht gekregen (\%) & 29 & 25 & 30 & n.s. \\
\hline $\begin{array}{l}\text { Rapportcijfer kwaliteit berichtgeving* (gemiddelde, } \\
\text { (SD)) }\end{array}$ & $5,3(2,3)^{3}$ & $4,8(2,4)^{1}$ & $5,0(2,4)$ & $\mathrm{p}<0,01$ \\
\hline Geregeld overleg (\%) & 27 & 25 & 29 & n.s. \\
\hline $\begin{array}{l}\text { Rapportcijfer kwaliteit van overleg* (gemiddelde, } \\
\text { (SD)) }\end{array}$ & $6,7(1,7)$ & $6,8(1,6)$ & $6,7(1,8)$ & n.s. \\
\hline Knelpunten in de samenwerking (\%) & 64 & 62 & 59 & n.s. \\
\hline Gemiddeld aantal knelpunten (maximum van 4) & 1,1 & 1,1 & 1,0 & n.s. \\
\hline \multicolumn{5}{|l|}{$\begin{array}{l}\text { Ervaringen van huisartsen ten aanzien van samen- } \\
\text { werking met de ELP }\end{array}$} \\
\hline $\begin{array}{l}\text { Kennis van hulpverleningsaspecten: namen en } \\
\text { werkwijze (\%) }\end{array}$ & 85 & 88 & 91 & $\mathrm{p}<0,01$ \\
\hline Bericht gekregen (\%) & 59 & 57 & 62 & n.s. \\
\hline $\begin{array}{l}\text { Rapportcijfer kwaliteit berichtgeving* (gemiddelde, } \\
\text { (SD)) }\end{array}$ & $6,8(1,7)$ & $6,7(1,8)$ & $6,9(1,5)$ & n.s. \\
\hline Geregeld overleg (\%) & 12 & 15 & 20 & $\mathrm{p}<0,01$ \\
\hline $\begin{array}{l}\text { Rapportcijfer kwaliteit van overleg* (gemiddelde, } \\
\text { (SD)) }\end{array}$ & $7,1(1,4)$ & $7,2(1,4)$ & $7,3(1,3)$ & n.s. \\
\hline Knelpunten in de samenwerking (\%) & 56 & 54 & 42 & $\mathrm{p}<0,01$ \\
\hline $\begin{array}{l}\text { Gemiddeld aantal knelpunten in de samenwerking } \\
\text { (maximum van } 4 \text { knelpunten) }\end{array}$ & $0,8^{5}$ & $0,7^{5}$ & $0,6^{1,3}$ & $\mathrm{p}<0,01$ \\
\hline
\end{tabular}

Noot: ${ }^{1,3,5}$ staan respectievelijk voor de jaren 2001, 2003 en 2005 en geven aan dat de bijbehorende waarde significant verschilt van de aangegeven jaren.

* Het rapportcijfer loopt van 1 tot 10 
Emmen, M.J., Meijer, S.A., Heideman, J.M.C., Laurant, M.G.H., Verhaak, P.F.M. Versterking van de eerstelijns GGZ: effecten op langere termijn. TSG: Tijdschrift voor Gezondheidswetenschappen: 2007, 85(3), 166

Tabel 3 Indicatoren voor samenwerking met de tweedelijns GGZ

\begin{tabular}{|c|c|c|c|c|}
\hline $\begin{array}{l}\text { Ervaringen van huisartsen ten aanzien van samenwerking } \\
\text { met de ambulante GGZ }\end{array}$ & $\begin{array}{c}2001 \\
(n=846-1336)\end{array}$ & $\begin{array}{c}2003 \\
(n=969-1341)\end{array}$ & $\begin{aligned} & 2005 \\
&(n=609-729)\end{aligned}$ & \\
\hline $\begin{array}{l}\text { Kennis van hulpverleningsaspecten: namen en werkwijze } \\
(\%)\end{array}$ & 81 & 88 & 87 & $\mathrm{p}<0,01$ \\
\hline Bericht gekregen (\%) & 85 & 86 & 85 & n.s. \\
\hline Rapportcijfer kwaliteit berichtgeving* (gemiddelde, (SD)) & $6,8(1,2)^{3,5}$ & $7,0(1,2)^{1}$ & $7,1(1,2)^{1}$ & $\mathrm{p}<0,01$ \\
\hline Geregeld overleg (\%) & 13 & 19 & 21 & $\mathrm{p}<0,01$ \\
\hline Rapportcijfer kwaliteit van overleg* (gemiddelde, (SD)) & $6,8(1,3)^{3,5}$ & $7,1(1,2)^{1}$ & $7,0(1,3)^{1}$ & $\mathrm{p}<0,01$ \\
\hline Knelpunten in de samenwerking (\%) & 89 & 82 & 76 & $\mathrm{p}<0,01$ \\
\hline $\begin{array}{l}\text { Gemiddeld aantal knelpunten in de samenwerking (maxi- } \\
\text { mum van } 4 \text { knelpunten) }\end{array}$ & $1,9^{3,5}$ & $1,7^{1,5}$ & $1,5^{1,3}$ & $\mathrm{p}<0,01$ \\
\hline
\end{tabular}
mum van 4 knelpunten)

Noot: ${ }^{1,3,5}$ staan respectievelijk voor de jaren 2001, 2003 en 2005 en geven aan dat de bijbehorende waarde significant verschilt van de aangegeven jaren.

${ }^{*}$ Het rapportcijfer loopt van 1 tot 10

Tabel 4 Gevolgde bij-/nascholing

\begin{tabular}{|c|c|c|c|c|}
\hline & $\begin{array}{c}2001 \\
(n=1220-1227)\end{array}$ & $\begin{array}{c}2003 \\
(n=1279-1307)\end{array}$ & $\begin{array}{c}2005 \\
(n=705-712)\end{array}$ & \\
\hline $\begin{array}{l}\text { Bij-/nascholing GGZ in uren (gemiddelde, } \\
\text { (SD)) }\end{array}$ & $12,1(9,5)^{3,5}$ & $10,5(9,2)^{1}$ & $10,2(9,9)^{1}$ & $\mathrm{p}<0,01$ \\
\hline Proportie GGZ bij- / nascholing(\%) & $16,6(14,8)^{3,5}$ & $14,2(13,4)^{1}$ & $14,2(15,4)^{1}$ & $\mathrm{p}<0,01$ \\
\hline
\end{tabular}

Noot: ${ }^{1,3.5}$ staan respectievelijk voor de jaren 2001, 2003 en 2005 en geven aan dat de bijbehorende waarde significant verschilt van de aangegeven jaren.

Tabel 5 Aantal patiënten per 1000 ingeschrevenen dat de huisarts naar schatting in het afgelopen jaar heeft doorverwezen

\begin{tabular}{lccc}
\hline Verwijzingen/1000 patiënten & $\begin{array}{c}\mathbf{2 0 0 1} \\
(\mathbf{n = 1 0 8 0 - 1 0 9 2 )}\end{array}$ & $\begin{array}{c}\mathbf{2 0 0 3} \\
(\mathbf{n = 1 1 9 0 - 1 2 1 7})\end{array}$ & $\begin{array}{c}\mathbf{2 0 0 5} \\
(\mathbf{n = 6 5 6 - 6 5 9 )}\end{array}$ \\
\hline Algemeen Maatschappelijk Werk & $8,7(9,2)$ & $8,1(9,5)$ & $8,9(11,7)$ \\
Eerstelijnspsycholoog & $8,9(9,3)$ & $9,2(10,2)$ & n.s. \\
Ambulante GGZ & $9,7(10,7)$ & $9,5(8,7)$ & n.s. \\
Totaal & $26,6(22,6)$ & $26,4(26,7)$ & n.s. \\
\hline
\end{tabular}

